\title{
UPAYA PENINGKATAN AKTIVITAS DAN HASIL BELAJAR SISWA DENGAN MENGGUNAKAN MODEL PEMBELAJARAN INKURI TERBIMBING PADA SISWA KELAS XI-1 SMP NEGERI 1 SECANGGANG
}

\author{
Endang Suharningsih
}

Surel : endangsuharningsih@yahoo.com

\begin{abstract}
ABSTRAK
Tujuan penelitian ini yaitu: Untuk mengetahui bagaimana cara menerapan model pembelajaran inkuri Terbimbing untuk meningkatkan aktivitas belajar dan hasil belajar siswa kelas IX-1 di Kelas IX-1 SMP Negeri 1 Secanggang Kab. Langkat. Prosedur penelitian ini direncanakan 2 siklus. Hasil belajar yang diperoleh yaitu pada siklus I hasil belajar siswa diperoleh 18 orang tuntas belajar atau sekitar $56,25 \%$ dan 14 orang atau sekitar $43,75 \%$ tidak tuntas belajar, terjadi peningkatan pada siklus II diperoleh hasil belajar siswa 28 orang tuntas belajar atau sekitar $87,5 \%$ dan 4 orang atau sekitar 12,5\% tidak tuntas belajar. Dari hasil belajar tersebut terjadi peningkatan dari siklus I ke siklus II, hasil belajar diatas dapat disimpulkan telah mencapai ketuntasan belajar secara klasikal yang ditargetkan yaitu $85 \%$ tuntas belajar dalam 1 kelas.
\end{abstract}

Kata Kunci: Inkuiri Terbimbing, Aktivitas, Hasil belajar

\section{PENDAHULUAN}

Mata pelajaran matematika bertujuan agar peserta didik memiliki kemampuan berikut: (1) memahami konsep matematika, menjelaskan keterkaitan antarkonsep dan mengaplikasikan konsep atau algoritma, secara luwes, akurat, efisien, dan tepat, dalam pemecahan masalah; (2) menggunakan penalaran pada pola dan sifat, melakukan manipulasi matematika dalam membuat generalisasi, menyusun bukti, atau menjelaskan gagasan dan pernyataan matematika; memecahkan masalah yang meliputi kemampuan memahami masalah, merancang model matematika, menyelesaikan model dan menafsirkan solusi yang diperoleh.; (4) mengomunikasikan gagasan dengan simbol, tabel, diagram, atau media lain untuk memperjelas keadaan atau masalah. Tujuan pembelajaran matematika diatas harus dicapai dengan baik karena matematika merupakan mata pelajaran yang hampir mencakup semua aspek bidang ilmu yang lain. Namun dalam hasil refleksi yang dilakukan di SMP Negeri I Secanggang Kab. Langkat khususnya di kelas IX 1 pada semester ganjil ditemukan bahwa (1) pembelajaran matematika yang dilakukan hanya dengan menggunakan metode ceramah sehingga siswa merasa bosan; (2) siswa merasa sulit karena mata pelajaran matematika memerlukan kalkulasi angka-angka yang beragam; (3) aktivitas kelas pasif, siswa banyak diam di tempat duduk tanpa adanya interaksi timbal balik antara guru dan siswa. 
Berdasarkan hasil refleksi diatas, dapat disimpulkan bahwa proses pembelajaran di kelas masih belum terjadi dua arah yang mengakibatkan siswa tidak banyak beraktivitas dalam proses belajar. Metode ceramah yang selalu digunakan menjadi penyebab rendahnya aktivtas belajar siswa tersebut. Oleh sebab itu, perlu kiranya dilakukan perubahan-perubahan dalam proses mengajar tersebut sehingga masalahmasalah yang ditemukan dapat teratasi.

Model pembelajaran inkuiri merupakan model pembelajaran yang cukup tepat diterapkan dalam proses pembelajaran matematika karena model ini berbasis penemuan. Model pembelajaran inkuiri diartikan sebagai proses pembelajaran yang didasarkan pada pencarian dan penemuan melalui proses berpikir secara sistematis. Siswa akan dituntut untuk menemukan serta mencari jawaban atas suatu permasalahan yang tentunya dilakukan dengan cara sistematis, logis dan kritis dan dianalisis dengan perhitungan yang matang.

\section{METODE PENELITIAN}

\begin{tabular}{lrr}
\multicolumn{2}{c}{ Prosedur } & perbaikan \\
pembelajaran & meliputi & kegiatan \\
pelaksanaan penelitian & tindakan
\end{tabular}
kelas yang disusun oleh Kemmis dan Mc Targgat yang terdiri dari 4 tahap yaitu perencanaan tindakan observasi dan refleksi, serta pelaksanaan penelitian ini dilaksanakan 2 siklus.

\section{HASIL PENELITIAN DAN PEMBAHASAN}

Hasil evaluasi diri dan diskusi yang dilakukan dengan teman sejawat dilakukan Penelitian Tindakan Kelas yang menggunakan model pembelajaran inkuri di kelas IX-1 yang memiliki masalah, penerapan model tersebut pad materi konsep dasar peluang dengan kriteria ketuntasan minimum 70, setelah melaksanakan pembelajaran dan dilakukan proses penilaian diperoleh data hasil belajar siswa dapat dilihat pada Grafik dibawah ini :

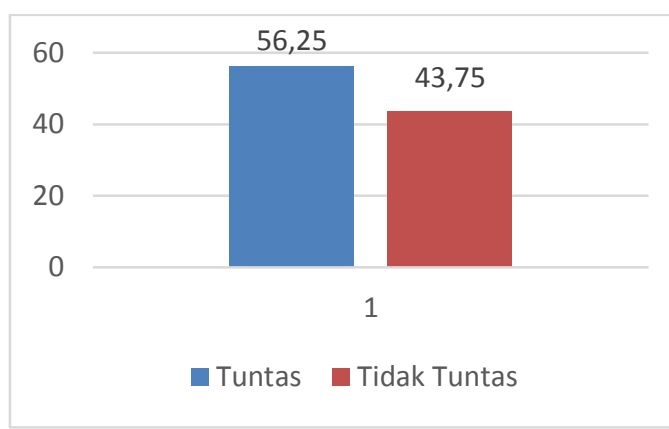

\section{Grafik Ketuntasan Hasil Belajar Siswa Pada Siklus I}

Dapat dilihat hasil belajar siswa pada siklus I pada mata pelajaran Matematika di SMP Negeri I Secanggang Kelas IX-1 dengan menggunakan inkuiri terbimbing, diperoleh 18 orang tuntas belajar atau sekitar 56,25\% dan 14 orang atau sekitar 437,5 \% tidak tuntas belajar.

Setelah mengamati hasil dari hasil belajar dan aktivitas siswa dan melakukan diskusi dengan teman sejawat dari hasil refleksi siklus I, maka siklus II dilanjutkan dengan perbaikan-perbaikan penyempurnaan 
bahan-bahan materi dan lama proses diskusi dan juga dipantau, menambah motivasi kepada siswa kemudian dirancang kembali RPP dengan menggunakan model pembelajaran inkuiri terbimbing dengan Kriteria Ketuntasan Minimum 70, setelah melaksanakan pembelajaran dan dilakukan proses penilaian diperoleh data hasil belajar siswa dapat dilihat pada grafik dibawah ini:

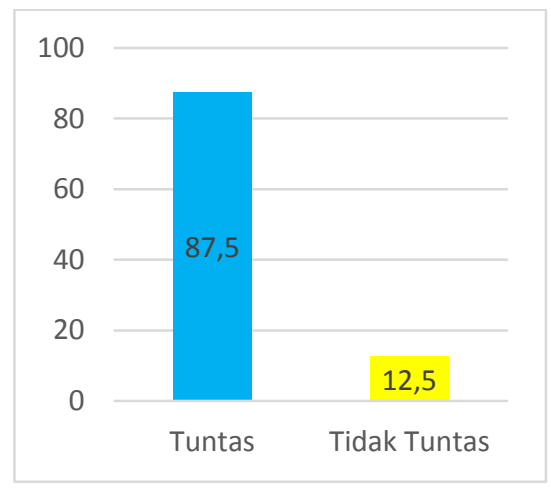

\section{Grafik Ketuntasan Hasil Belajar Siswa Pada Siklus II}

Dapat dilihat hasil belajar siswa pada siklus II pada mata pelajaran Matematika di SMP Negeri I Secanggang Kelas IX-1 dengan menggunakan model pembelajaran inkuiri terbimbing, diperoleh hasil belajar siswa 28 orang tuntas belajar atau sekitar $87,5 \%$ dan 4 orang atau sekitar $12,5 \%$ tidak tuntas belajar. Dari hasil belajar tersebut terjadi peningkatan dari siklus I ke siklus II, hasil belajar diatas dapat disimpulkan telah mencapai ketuntasan belajar secara klasikal yang ditargetkan yaitu $85 \%$ tuntas belajar dalam 1 kelas.

\section{Pembahasan}

Penerapan pembelajaran model pembelajaran inkuiri terbimbing pada pembelajaran Matematika pada siswa kelas IX-1 di SMP Negeri 1 Secanggang menunjukkan adanya peningkatan ketercapaian indikator hasil belajar siswa dan aktivitas belajar siswa. Berikut ini penjelasan ketercapaian target pada setiap aspek hasil belajar dan aktivitas belajar.

Pada siklus I pada mata pelajaran Matematika pada siswa kelas IX-1 di SMP Negeri 1 Secanggang dengan model pembelajaran inkuiri terbimbing diperoleh 18 orang tuntas belajar atau sekitar 56,25\% dan 14 orang atau sekitar $43,75 \%$ tidak tuntas belajar, sedangkan untuk aktivitas belajar ada 4 aspek yang diamati yaitu: kemampuan presentasi, kemampuan berargumentasi, kemampuan menjawab dan penguasaan materi. Dari 4 aspek yang diamati dapat dilihat bahwa 3 kelompok dalam aspek kemampuan berargumentasi dan kemampuan menjawab pertanyaan masih rendah. Kelompok monopoli merupakan kelompok dengan aktivitas paling rendah pada siklus I dengan nilai 56,25. Dari hasil siklus I ini hasil belajar dan aktivitas siswa masih belum maksimal dikarenakan: a) Penyampaian materi belum tuntas; b) Tidak menggunakan media secara maksimal; c) Siswa belum jelas terhadap konsep dan materi yang diberikan. d) pembahasan materi dan sumber materi yang tidak maksimal. 
Selanjutnya untuk melakukan perbaikan siklus I peneliti melakukan perbaikan , antara lain: a) Memberi motivasi pada siswa untuk lebih meningkatkan keaktifan dalam proses pembelajaran dan presentase; b) Guru lebih intensif membimbing siswa/kelompok yang mengalami kesulitan. Pada siklus II pada pembelajaran Matematika pada siswa kelas IX-1 di SMP Negeri 1 Secanggang, diperoleh hasil belajar siswa 28 orang tuntas belajar atau sekitar $87,5 \%$ dan 4 orang atau sekitar $12,5 \%$ tidak tuntas belajar, hasil belajar diatas dapat disimpulkan telah mencapai ketuntasan belajar secara klasikal yang ditargetkan yaitu $85 \%$ tuntas belajar dalam 1 kelas. Aktivitas yang diamati selama pembelajaran dengan menerapkan metode model pembelajaran inkuri terbimbing ada 4 aspek yang diamati yaitu : kemampuan presentasi, kemampuan berargumentasi, kemampuan menjawab dan penguasaan materi. Dari 4 aspek yang diamati dapat dilihat bahwa terjadi peningkatan kemampuan siswa dalam presentase dan penguasaan materi yang sangat baik dalam presentasi, dari segi aspek kemampuan berargumentasi dan kemampuan menjawab pertanyaan juga terjadi peningkatan yang sangat baik. Dari hasil observasi diatas dan hasil belajar siswa diatas dapat ditarik kesimpulan penerapan pembelajaran dengan model inkuiri dapat meningkatkan aktivitas dan hasil belajar siswa dengan baik. Sejalan dengan hasil penelitian Dwidayani, dkk (2014) Penerapan metode pembelajaran Inkuiri pada mata pelajaran IPS dapat meningkatkan hasil belajar siswa secara efektif.

\section{SIMPULAN}

Berdasarkan temuan hasil penelitian tentang Upaya Meningkatkan Aktivitas dan Hasil Belajar Siswa Pada Pelajaran Matematika Dengan Menggunakan Model Pembelajaran Inkuri Terbimbing Di Kelas IX-1 SMP Negeri I Secanggang Kab. Langkat", dapat ditarik kesimpulan sebagai berikut :

a. Pada siklus I hasil belajar siswa diperoleh 18 orang tuntas belajar atau sekitar 56,25\% dan 14 orang atau sekitar $43,75 \%$ tidak tuntas belajar, terjadi peningkatan pada siklus II diperoleh hasil belajar siswa 28 orang tuntas belajar atau sekitar $87,5 \%$ dan 4 orang atau sekitar $12,5 \%$ tidak tuntas belajar. Dari hasil belajar tersebut terjadi peningkatan dari siklus I ke siklus II, hasil belajar diatas dapat disimpulkan telah mencapai ketuntasan belajar secara klasikal yang ditargetkan yaitu $85 \%$ tuntas belajar dalam 1 kelas.

b. Hasil pengamatan aktivitas belajar siswa diperoleh data sebagai berikut, untuk siklus I memperoleh nilai diantaranya: Kelompok Ludo 68,75, Kelompok Monopoli 56,25, kelompok Ludo 62,5, Kelompok 
SEJ VOLUME 7 NO. 2 JUNI 2017

Halma 62,5 terjadi peningkatan yang signifikan pada siklus II yaitu: Kelompok Ludo 93,75, Kelompok Monopoli 93,75, kelompok Ludo 81,25, Kelompok Halma 87,5. Dapat ditarik simpulan bahwa pembelajaran dengan menggunakan Metode Pembelajaran Model Pembelajaran Inkuri Terbimbing juga dapat meningkatkan aktivitas belajar siswa.

\section{DAFTAR RUJUKAN}

Aburrahman. 2003. Pendidikan Bagi Anak Kesulitan Belajaran. Jakarta: Rienka Cipta

Gagne, R.M., \& Briggs, L.J. 1979. Principle of Instructional Design. New Yorks: Holt Rinehart and Winston.

Jackson, P.W. 1992. Handbook of Reseasrch on Curriculum. New York: A Project of American
Educational Research Association.

Prambudi, Sohim. 2010. Bisik-Bisik Tetangga Strategi Pembelajaran Inkuiri. Jakarta: Rienka Cipta.

Syaiful, Bahri dan Aswan Zain. 2010. Strategi Belajar Mengajar. Jakarta: Rineka Cipta

Sukmadinata, Nana Sy. 2004. Pengembangan Kurikulum: Teori dan Praktek. Bandung: Rosdakarya.

The, Liang Gie. 1985. Cara Belajar Yang Efisien. Yogjakarta: Pusat Kemajuan Studi (Centre For Study Progress)

Usman, Muh. User, Lilis Setiawati. 1993. Upaya Optimalisasi Kegiatan Belajar Mengajar. (Bahan Kajian PKG, MGBS, MGMP). Bandung: PT. Remaja Rosdakarya. 